\title{
The management of head-and-neck paragangliomas
}

\author{
Cristina Capatina, Georgia Ntali, Niki Karavitaki and Ashley B Grossman \\ Oxford Centre for Diabetes, Endocrinology and Metabolism, University of Oxford, Oxford OX3 7LE, UK
}

Correspondence should be addressed to A B Grossman Email

ashley.grossman@

ocdem.ox.ac.uk

\begin{abstract}
Paragangliomas (PGLs) are tumours originating from neural crest-derived cells situated in the region of the autonomic nervous system ganglia. Head-and-neck PGLs (HNPGLs) originate from the sympathetic and parasympathetic paraganglia, most frequently from the carotid bodies and jugular, tympanic and vagal paraganglia, and are usually non-catecholamine secreting. Familial PGLs are considered to be rare, but recently genetic syndromes including multiple PGLs and/or phaeochromocytomas have been more thoroughly characterised. Nowadays, genetic screening for the genes frequently implicated in both familial and sporadic cases is routinely being recommended. HNPGLs are mostly benign, generally slow-growing tumours. Continuous growth leads to the involvement of adjacent neurovascular structures with increased morbidity rates and treatment-related complications. Optimal management mostly depends on tumour location, local involvement of neurovascular structures, estimated malignancy risk, patient age and general health. Surgery is the only treatment option offering the chance of cure but with significant morbidity rates, so a more conservative approach is usually considered, especially in the more difficult cases. Radiotherapy (fractionated or stereotactic radiosurgery) leads to tumour growth arrest and symptomatic improvement in the short term in many cases, but the longterm consequences are unclear. Early detection is essential in order to increase the chance of cure with a lower morbidity rate. The constant improvement in diagnostic imaging, surgical and radiation techniques has led to a safer management of these tumours, but there are still many therapeutic challenges, and no treatment algorithm has been agreed upon until now. The management of HNPGLs requires a multidisciplinary effort addressing the genetic, surgical, radiotherapeutic, oncological, neurological and endocrinological implications. Further progress in the understanding of their pathogenesis will lead to more effective screening and earlier diagnosis, both critical to successful treatment.
\end{abstract}

\author{
Key Words \\ - paragangliomas \\ - therapy \\ - management \\ - surgery \\ radiotherapy
}

\section{Introduction}

Paragangliomas (PGLs) are rare tumours originating from paraganglia - small groups of neuroendocrine cells arising from the autonomic nervous system ganglia. The sympathetic paraganglia are mostly located along the sympathetic nerve chains bordering the vertebrae and in the pelvis, while the parasympathetic ones are primarily located in the head and neck and less frequently located in the thorax or pelvis. Tumours arising from the

Published by Bioscientifica Ltd 
parasympathetic paraganglia are usually non-chromaffin and only rarely secrete catecholamines, when compared with their sympathetic counterparts (Barnes et al. 2004).

Head-and-neck PGLs (HNPGLs) are rare tumours, representing $0.012 \%$ of a large oncological surgical series (Lack et al. 1977); the estimated clinical incidence is 1/100 000 patients per year (Baysal 2002). The classical main sites of origin are as follows: carotid bodies (at the bifurcation of the common carotid artery); jugular paraganglia (close to the jugular bulb) and tympanic paraganglia (in the middle ear) - usually considered together (JTPGLs); and vagal paraganglia (along the vagus nerve). The most frequently found are the carotid body tumours (CBTs) and the least frequent are those arising from the vagus paraganglia (VPGLs). The relative frequencies across series in the literature vary widely: in a large reported series of 204 HNPGLs, 57\% were CBTs, 30\% JTPGLs and 13\% VPGLs (Erickson et al. 2001).

Increasingly, due to their association with phaeochromocytomas and new genetic data, these tumours are being diagnosed by endocrinologists and oncologists, but much of the published literature is in more specialised ENT or surgical journals. We think that it will be useful to survey current data on the management of these tumours in order to assist clinicians in advising their patients on the most appropriate therapy.

\section{Genetic background}

HNPGLs were occasionally described in rare conditions such as von Hippel-Lindau disease (Zanelli \& van der Walt 1996, Gaal et al. 2009), multiple endocrine neoplasia type 2 (Boedeker et al. 2009a), neurofibromatosis (DeAngelis et al. 1987) and Carney's triad (Carney et al. 1977). Until quite recently, most PGLs were considered sporadic, unless there was a positive family history $(\mathrm{FH})$ or if co-morbidities characteristic of the known genetic syndromes were present. However, many newly characterised genes have been found to be mutated in many apparently sporadic PGLs. Currently, four genetic PGL syndromes are being described, all with autosomal dominant transmission. Three of these syndromes are associated with germline mutations in the gene complex encoding succinate dehydrogenase (SDH): PGL-1, PGL-3 and PGL-4, caused by mutations in $S D H D, S D H C$ and $S D H B$ respectively. All these mutations predispose to PGLs in all locations and/or phaeochromocytomas. HNPGLs are frequent in the PGL-1 syndrome due to SDHD mutations and are frequently multifocal and also in the PGL-3 syndrome due to SDHC mutations; they are more rare but more frequently malignant in the PGL-4 syndrome secondary to $S D H B$ mutations. In the PGL-1 syndrome, genomic imprinting has consistently been described; the maternally derived allele is imprinted, so this means that only mutations inherited from the father are pathogenic (Niemann et al. 1999, Baysal et al. 2000, Astuti et al. 2001, GimenezRoqueplo et al. 2012). The causal mutation of the PGL-2 syndrome has only recently been described (SDHAF2 gene; Hao et al. 2009), is very rare (Bayley et al. 2010) and its transmission is also consistent with genomic imprinting (Kunst et al. 2011).

\section{Genetic screening}

Apparently sporadic PGLs harbour $S D H$-related mutations in a significant proportion of the cases $(30.6 \%)$; the likelihood of having a $S D H$ mutation is best predicted by a positive $\mathrm{FH}$, multicentricity and a previous phaeochromocytoma and, to a lesser extent, by young age, male gender and malignancy (Neumann et al. 2009). Therefore, sequential genetic screening guided by clinical predictive factors has been recommended, although parallel sequencing of multiple genes is carried out in some centres, including our centre (Young 2006, Burnichon et al. 2009). The loss of the normal immunohistochemical staining of paraganglial cells with antibodies against the SDHB protein has recently been found to be highly associated with germline mutations of all the SDH complex genes (van Nederveen et al. 2009). Greater experience is needed with this elegant potential screening tool, but it promises to become a routine part of the screening as immunonegativity for the SDHB protein is consistently associated with $S D H$-related tumours and is not found in sporadic or non-SDH mutation-related cases. In an international study, the penetrance of gene mutations has been found to be $48 \%$ for $S D H D$ at 30 years of age and $73 \%$ by 40 years of age, vs 29 and $45 \%$ respectively for SDHB (Benn et al. 2006). Thus, the high penetrance of SDHD mutations suggests that they are rarely found in patients presenting tumours beyond 45 years of age (Cascon et al. 2009). In a large UK study, the majority of the mutations missed using an age cut-off were in the $S D H B$ gene; these authors suggested that if genetic testing for $S D H B$ is limited to younger patients on cost grounds, it should be complemented with SDHB immunostaining (Jafri et al. 2013).

It has been suggested that genetic testing for VHL, RET and NF1 mutations may be considered if there is clinical suspicion (Boedeker et al. 2009a,b) and for SDHAF2 in high-risk patients negative for other $S D H$ mutations (Bayley et al. 2010), while two other newly described

Published by Bioscientifica Ltd. 
genes (TMEM127 and MAX) are rarely implicated in HNPGLs (Gimenez-Roqueplo et al. 2012). However, as has been noted above, we routinely screen for all the genes currently implicated in HNPGLs other than NF1; the latter has a very large number of exons, and the clinical syndrome is (almost always) obvious.

\section{Clinical presentation}

HNPGLs rarely release catecholamines to produce a hypersecretory syndrome $(<10 \%)$. In the vast majority of cases, they are discovered due to the mass effects dominated by the involvement of lower cranial nerves (CNs) IX and X; $10 \%$ are diagnosed incidentally (Erickson et al. 2001).

HNPGLs in the lower part of the neck (CBTs and some VPGLs) usually present as painless, sometimes pulsatile, neck masses. With further growth, they involve the lower $\mathrm{CNs}$, leading to speech and swallowing deficits (hoarseness and dysphagia) and sometimes to aspiration (Miller et al. 2000, Offergeld et al. 2012). A preoperative CN deficit is frequently observed in VPGLs (25-36\%) and JTPGLs (39-40\%) and less so in CBTs (4-22\%) (Powell et al. 1992, Netterville et al. 1998, Sajid et al. 2007, Neskey et al. 2011).

Intracranial extension is rare in CBTs (Rao et al. 1999) and more frequent in VPGLs - 22\% (Netterville et al. 1998). JTPGLs are intracranial tumours, and it is often difficult to delineate their site of origin: tympanic tumours may extend towards the jugular bulb and posterior fossa, while jugular tumours can involve the temporal bone and extend into the middle ear. Intracranial invasion and involvement of the $\mathrm{CN}$ adjacent to the jugular foramen can lead to pulsatile tinnitus, an ear mass, hearing loss, pain and vertigo as major presenting symptoms in JTPGLs and high VPGLs (Cummings et al. 1984, Persky et al. 2002, Offergeld et al. 2012).

HNPGLs are most frequently diagnosed in middleaged adults (mean age 41-47 years; Erickson et al. 2001, Jackson et al. 2001, Papaspyrou et al. 2009). Genetic cases are more than a decade younger (Burnichon et al. 2009). A FH should be sought in all the cases; positivity is highly variable among series, but can reach over $80 \%$ in populations with a high frequency of founder $S D H D$ mutations (Hensen et al. 2011). A positive FH increases the risk of multifocality: up to $78 \%$ of the cases with a positive $\mathrm{FH}$ and $17-37 \%$ of the unselected cases are multicentric (Jackson et al. 1990, Netterville et al. 1998, Erickson et al. 2001, Plukker et al. 2001, Sajid et al. 2007, Papaspyrou et al. 2009).

Malignancy can only be ascertained in the presence of distant metastases. None of the markers in a large set of putative markers of malignancy can reliably predict malignancy, and tumour size is still the major indicator of risk, as it is for phaeochromocytomas (Korevaar \& Grossman 2011). The risk of malignancy is higher in $S D H B$ mutation carriers, while multifocality is more frequent in SDHD germline mutations (Burnichon et al. 2009). In large series, evidence of malignancy in 3-5\% of the HNPGL cases (Manolidis et al. 1999, Jafri et al. 2013) with a lower risk for CBTs and JTPGLs (2-6\%) and a higher risk (16\%) for VPGLs has been found (Kahn 1976, Kloppel 2003). Distant metastases may occur even after 16 years of followup (Lees et al. 1981), so long surveillance is critical for a precise estimate of the real incidence. The most common site of distant spread is the cervical lymph nodes (68.6\%; Lee et al. 2002); other sites are the bone, lung and liver (Moskovic et al. 2010).

The overall 5-year survival in malignant cases is generally good (59.5-84\%; Manolidis et al. 1999, Lee et al. 2002, Moskovic et al. 2010), but it becomes disappointing (11.8\%) if cases with only local spread are excluded (Lee et al. 2002).

\section{Classification}

\section{Shamblin classification of CBTs}

The CBT classification of Shamblin et al. (1971) is still in use and shows a good correlation with surgical complications and outcome (Plukker et al. 2001, Luna-Ortiz et al. 2005, Makeieff et al. 2008). Tumours classified as class I have no or minimal attachment with the carotid arteries. Class II tumours surround the carotid arteries, partially encasing them. Shamblin class III tumours surround the vessels, adhering firmly over their whole circumference, so vessel resection and reconstruction are needed to attempt total tumour resection.

\section{Fisch classification of JTPGLS}

JTPGLs have been similarly classified by Fisch \& Mattox (1988): class A JTPGLs are located along the tympanic plexus on the promontory, and class B tumours invade the hypotympanum, but do not erode the jugular bulb, as opposed to class $\mathrm{C}$ tumours (C1 destruction of the jugular bulb/foramen; C2 invasion of the vertical carotid canal; C3 invasion of the horizontal carotid canal and C4 invasion of the cavernous sinus). In class $\mathrm{D}$ tumours, besides the various degrees of invasion described for class $C$, intracranial extradural or intradural extension occurs (De1 and De2 intracranial and extradural invasion of up to

Published by Bioscientifica Ltd. 
$2 \mathrm{~cm}$ or more than $2 \mathrm{~cm}$ respectively; Di1, Di2 and Di3 intracranial and intradural extension of up to $2 \mathrm{~cm}$, between 2 and $4 \mathrm{~cm}$ or more than $4 \mathrm{~cm}$ respectively).

\section{Diagnosis}

Plasma or 24-h urinary metanephrine or catecholamine concentrations should be measured in all HNPGLs, as they can (rarely) be secretory (Erickson et al. 2001). If catecholamine excess is demonstrated, an extensive workup should be performed to assess the possibility of synchronous phaeochromocytoma/sympathetic PGLs. Exclusive dopamine secretion was considered to be very rare, usually silent and possibly associated with a trend towards increased aggressiveness or malignant potential (Eisenhofer et al. 2005), but recently higher rates $(16.75-23 \%)$ of solely dopamine secretion or secretion of its metabolites have been described with these tumours (van Duinen et al. 2010, Van Der Horst-Schrivers et al. 2010). Chromogranin A is only rarely secreted (van Duinen et al. 2011). Thus, such markers are only useful in the follow-up of selected tumours.

Imaging is of paramount importance in patients with a clinical suspicion of HNPGLs or in individuals from affected families. Standard anatomical imaging (computerised tomography (CT) and magnetic resonance imaging (MRI)) is widely used as the initial evaluation method (see Figs 1, 2 and 3). CT has a lower sensitivity (Erickson et al. 2001), but accurately defines possible bone invasion. In MRI studies, PGLs show a characteristic 'salt-and-pepper' pattern (due to their vascularisation) and intense post-contrast enhance-

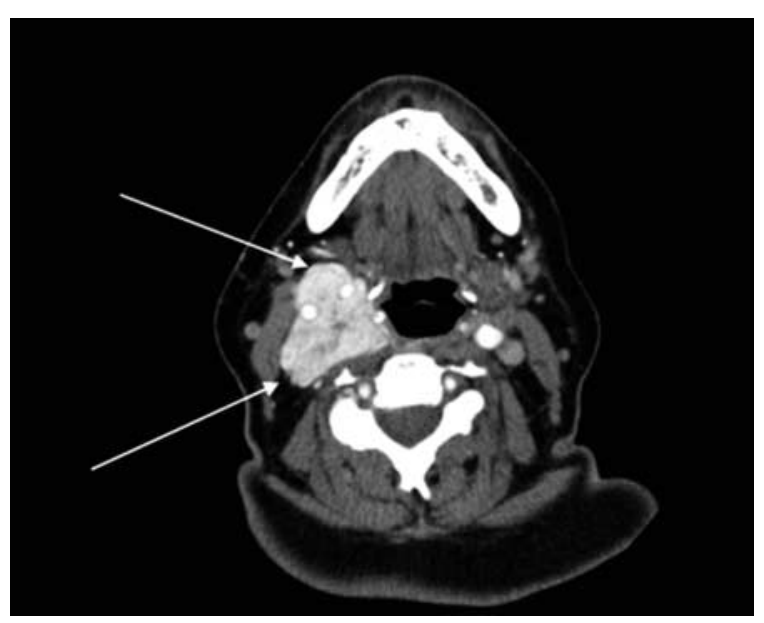

\section{Figure 1}

CT angiogram of the aortic arch and carotids a patient: a carotid bifurcation glomus tumour showing enhancement after contrast (arrows).

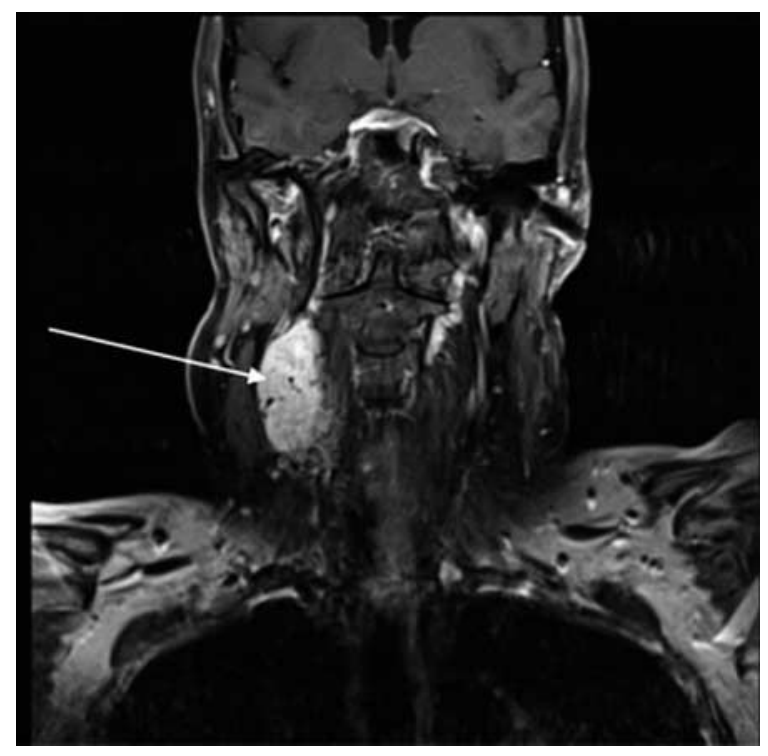

Figure 2

Cervical MRI of the patient illustrated in Fig. 1; the T1-weighted image shows the same lesion (arrow).

ment. Doppler-flow ultrasonography can be useful for the diagnosis and follow-up of CBTs (Rao et al. 1999).

Angiography (digital-subtraction angiography (DSA) or MRI angiography) is a key method for diagnosis, defining the vascular anatomy preoperatively (tumour blood supply and extent of the involvement of the carotid arteries), ensuring safe preparation in the event of major vascular reconstructive surgery, demonstrating the patency of cerebral blood flow and identifying multicentric disease. MRI angiography is technically preferable and safer, but it has a lower sensitivity than DSA (van den Berg et al. 2000).

Whole-body screening with functional imaging studies can detect possible synchronous lesions in confirmed mutation carriers or those at a high-risk of familial disease (positive FH and young age). ${ }^{123} \mathrm{I}$-MIBG (metaiodobenzylguanidine) scintigraphy, despite its high specificity, has a low sensitivity for the detection of HNPGLs. Its use for standard evaluation of HNPGLs is limited, and it is more frequently employed to assess tumour avidity for the tracer if radionuclide therapy is planned. Somatostatin receptor (SSR) scintigraphy has a better sensitivity, lower than that of standard anatomical imaging but offers whole-body scanning (Timmers et al. 2012, Gimenez-Roqueplo et al. 2013).

Positron-emission tomography (PET) has been used intensively as it can be used for the examination of the whole body with improved resolution, and it can detect small

Published by Bioscientifica Ltd http://erc.endocrinology-journals.org DOI: 10.1530/ERC-13-0223 (c) 2013 Society for Endocrinology Printed in Great Britain 


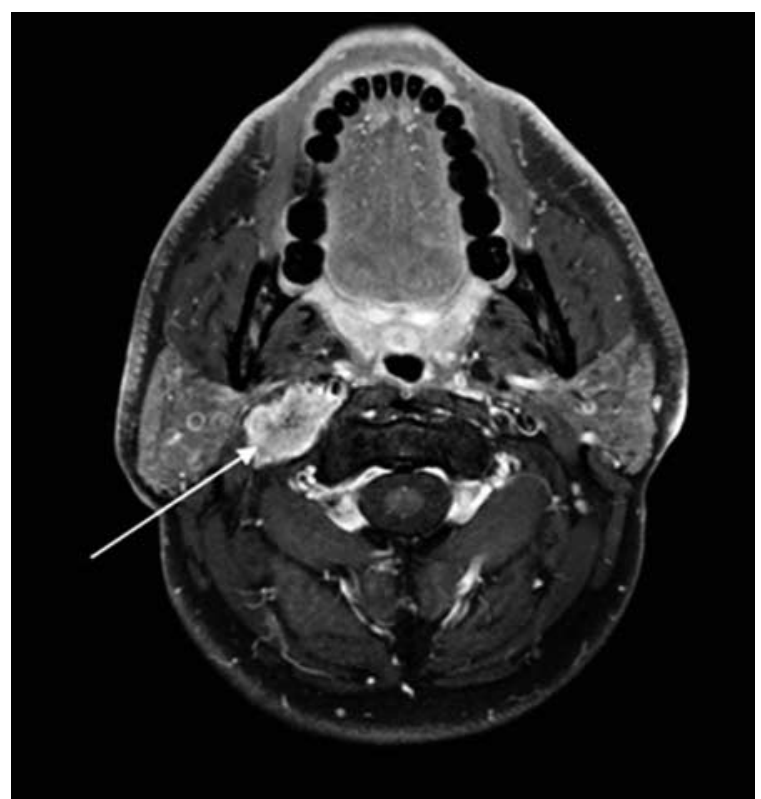

Figure 3

Neck MRI with gadolinium in another patient; the T1-weighted image shows a right-sided glomus jugulare tumour (arrow).

and metastatic lesions. ${ }^{18} \mathrm{~F}$-fluorodihydroxyphenylalanine $\left({ }^{18} \mathrm{~F}\right.$-DOPA) PET has a very good sensitivity for the detection of both unselected (Gabriel etal. 2013) and SDH-related HNPGLs (King et al. 2011). In a small group of HNPGLs of unknown genetic status, ${ }^{68}$ Ga-DOTANOC (DOTA-naphthyl-alanine conjugated with octreotide) PET/CT used for baseline evaluation is also significantly superior to CT, MRI and ${ }^{131}$ I-MIBG scintigraphy for the detection of multicentric disease or distant spread (Sharma et al. 2013).

Where available, ${ }^{18} \mathrm{~F}$-DOPA-PET should be used as the first-line functional imaging method for the detection of suspected HNPGLs (while in sympathetic PGLs, ${ }^{18} \mathrm{~F}$-fluorodopamine PET/CT is advocated as the first-line detection method). If unavailable, ${ }^{18}$ F-FDG- or ${ }^{68}$ Ga-DOTA-peptide-PET or SSR scintigraphy (if PET is not available) should be used to complement anatomical imaging studies (Timmers et al. 2009, Blanchet et al. 2011; see Figs 4 and 5).

\section{Natural history}

The natural history of HNPGLs is estimated based on the surveillance of selected patients without significant symptoms and/or poor candidates for treatment. In a study, of the 47 presumed HNPGLs observed for 5 years, on average, $42 \%$ were stable and $38 \%$ slowly increased in size (mean annual growth $0.2 \mathrm{~cm}$ ), while $20 \%$ decreased in size (any change in greatest dimension) (Langerman et al. 2012). Others have described a median growth rate of about $1 \mathrm{~mm}$ /year $(0.3-5 \mathrm{~mm})$ with a widely variable tumour doubling time (0.6-21.5 years), but overall $60 \%$ of the tumours increased by at least $20 \%$ of their original size over 1-8 years (average 4.2) (Jansen et al. 2000).

These results are generally considered reassuring, but the selection bias, short follow-up duration, lack of tumourassociated morbidity data and possible misdiagnosis or unrecognised malignant potential should be borne in mind.

\section{Management}

The main treatment modalities for PGLs include surgery and radiotherapy (external-beam radiotherapy (EBRT) or stereotactic radiosurgery (SRS)). The respective roles of chemotherapy and peptide receptor radionuclide therapy (PRRT) are yet to be clearly defined. Owing to the relatively mild natural history of HNPGLs, a long follow-up duration is needed before reaching a correct conclusion about the efficacy of any treatment.

\section{Surgery}

Whenever possible, complete surgical excision of the tumour is considered by many to be the favoured option of treatment in order to prevent morbidity associated with

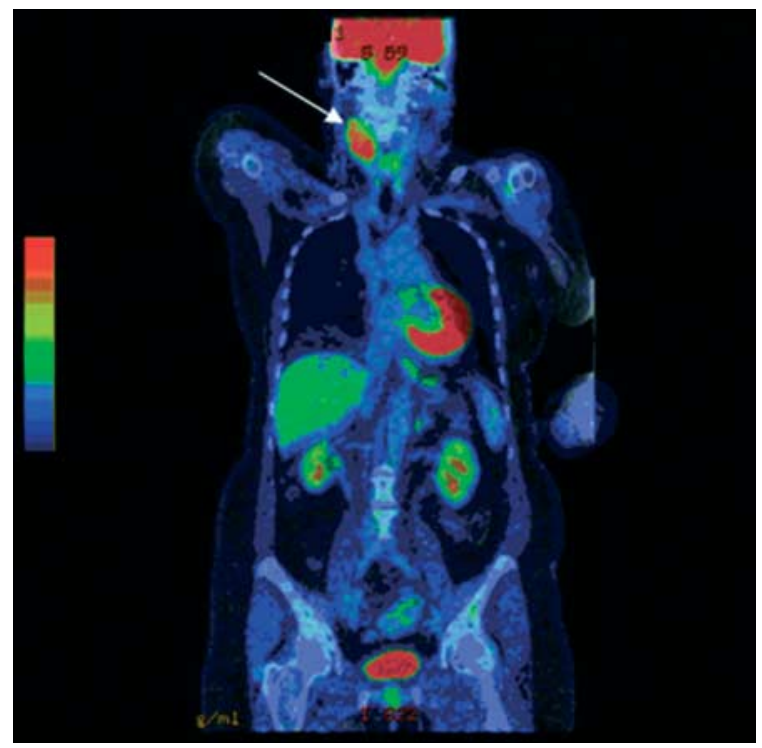

\section{Figure 4}

Whole-body ${ }^{18} \mathrm{FDG}$-PET/CT of the patient illustrated in Figs 1 and 2 showing an ovoid, moderately FDG-avid mass centred on the right side of the neck (arrow), lying deep to the sternomastoid and displacing the right submandibular gland anteriorly.

Published by Bioscientifica Ltd. 


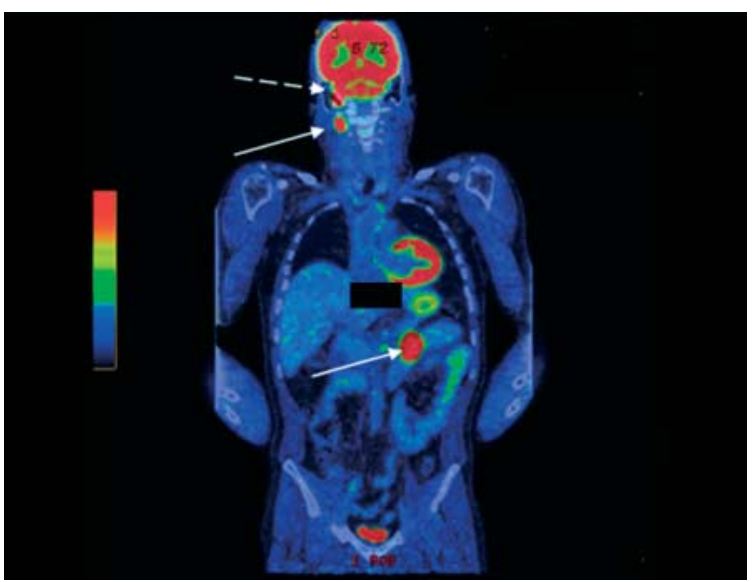

\section{Figure 5}

Whole-body ${ }^{18}$ FDG-PET/CT of the patient illustrated in Fig. 3 showing besides the intensely FDG-avid right jugular paraganglioma (dashed arrow), a vagal paraganglioma (solid arrow), which is markedly FDG avid, and a left-sided phaeochromocytoma (solid arrow), which is also intensely FDG avid.

further tumour growth or later spread from an unrecognised malignant tumour. Overall, gross total resection (GTR) is achievable in $90-97 \%$ of the cases with a low surgical mortality rate $(0-2.7 \%)$. However, surgery is associated with haemorrhagic, cerebrovascular and neurological risks (paresis of lower $\mathrm{CN}$ leading to swallowing and speech problems, aspiration, feeding tube or tracheostomy dependence, facial palsy and hearing loss; Erickson et al. 2001, Jackson et al. 2001, Kollert et al. 2006, Paris et al. 2006, Sevilla Garcia et al. 2007, Papaspyrou et al. 2009, Neskey et al. 2011, Obholzer et al. 2011). Adjuvant procedures to improve swallowing or hoarseness (e.g. vocal cord medialisation) are frequently used postoperatively, but complete rehabilitation of the complex neurological deficit is slow in younger patients and often impossible in the elderly (Netterville \& Civantos 1993), and thus indications for surgery should always be considered with great care.

\section{Particular surgical challenges are associated with different HNPGL locations}

\section{Carotid body tumours}

Complete surgical resection is possible in the vast majority (85-100\%) of CBTs and recurrences are rare (Lees et al. 1981, Gaylis et al. 1987, Rodriguez-Cuevas et al. 1998, Makeieff et al. 2008, Ma et al. 2009). However, surgical morbidity is still significant due to the high vascularity and proximity to essential neurovascular structures.
Significant intraoperative bleeding occurs, especially in advanced tumours (mean blood loss of $2200 \mathrm{ml}$ in Shamblin class III tumours; Plukker et al. 2001). To reduce bleeding, preoperative tumour embolisation has been advocated (Persky et al. 2002, Ulrich et al. 2009), but others have reported a lack of efficacy (Zeitler et al. 2010) and/or an increased risk of stroke (Westerband et al. 1998, Fruhmann et al. 2013), so its utility remains controversial. It is likely to be highly operator dependent and could be considered for large tumours, but only if there is appropriate local expertise.

The risk of transient ischaemic attack or stroke is higher in CBT surgery than in the surgery of tumours present in other locations. In an analysis of the postoperative outcome of 1181 patients, the cumulative incidence was found to be $6.3 \%$ (Anand et al. 1995), but was lower in more recent series, between 0 and $4.8 \%$ (Plukker et al. 2001, Luna-Ortiz et al. 2005, Sajid et al. 2007, Makeieff et al. 2008, Ma et al. 2009). A vascular surgeon should be an essential part of the surgical team as internal carotid artery injury occurs frequently (10-23\%) and vessel reconstruction leads to significantly lower stroke and mortality rates vs ligation (Anand et al. 1995, Plukker et al. 2001). Advances in surgical techniques and a multidisciplinary approach have led to a dramatic overall decrease in surgical mortality rates $-1 \%$ in a recent UK multicentre study (Sajid et al. 2007) vs 3.2\% in a literature review carried out in 1995 (Anand et al. 1995) and 12.82\% in older series (Lack et al. 1977).

Early postoperative $\mathrm{CN}$ deficits (lower $\mathrm{CN}$ palsies or, rarely, Horner's syndrome) are frequent (19-50\%), but a permanent deficit is less common due to progressive slow rehabilitation, 1-18\% (Plukker et al. 2001, Patetsios et al. 2002, Persky et al. 2002, Sajid et al. 2007, Makeieff et al. 2008). In advanced cases (Shamblin classes II and III), the rate of permanent neurological deficit can be up to $38 \%$ (Luna-Ortiz et al. 2005). The Shamblin classification is significantly correlated with postoperative complications (Makeieff et al. 2008), intraoperative blood loss (Plukker et al. 2001) and vascular reconstruction need (Smith et al. 2006), so early detection is essential for safe management.

A particular complication in CBT surgery is blood pressure instability (as the carotid body physiologically functions as a baroreceptor): both hypotension (Kohler et al. 2004) and, with bilateral resection, severe resistant hypertension (baroreceptor failure syndrome) can occur (De Toma et al. 2000). Chemoreflex dysfunction (absence of a normocapnic hypoxic ventilatory response) is almost universal, but baroreflex dysfunction occurs inconstantly (Timmers et al. 2003).

Published by Bioscientifica Ltd. 


\section{Vagus paraganglia}

The probability of surgical cure in VPGLs is also very high: GTR is possible in $92.3-100 \%$ of the cases with a low mortality rate (0-2.7\%) (Urquhart et al. 1994, Netterville et al. 1998, Jackson et al. 2001, Kollert et al. 2006). In a large literature review on VPGLs and JTPGLs published in 2012, Suarez et al. (2013a) described an average mortality rate of $1.3 \%$ with a GTR rate of $93.3 \%$.

However, the neurological risks are higher than those for CBTs: CN palsies are more common after surgery for JTPGLs and high-located VPGLs due to the tumoural involvement of the jugular foramen. An immediate postoperative $\mathrm{CN}$ palsy rate can be as high as 96 and 100\% respectively for these tumours (Neskey et al. 2011). The most affected component is the vagus nerve itself: in most series, a postoperative vagal deficit is almost universal (92-100\%), by either paresis or necessary sacrifice during surgery (Urquhart et al. 1994, Netterville et al. 1998, Jackson et al. 2001, Bradshaw \& Jansen 2005, Kollert et al. 2006, Zanoletti \& Mazzoni 2006).

Other new $\mathrm{CN}$ deficits postoperatively occur in $23-61 \%$ of the cases for nerves IX, XI and XII (mostly IX) and in $15-17 \%$ for the facial nerves (Urquhart et al. 1994, Jackson et al. 2001, Bradshaw \& Jansen 2005, Kollert et al. 2006, Zanoletti \& Mazzoni 2006, Lozano et al. 2008). Severe aspiration as a consequence occurs in $10.2 \%$ of the cases (Suarez et al. 2013a). The majority of patients need complex rehabilitation management regarding speech, swallowing and facial nerve deficits, but during follow-up, these deficits often recover partially (Netterville et al. 1998).

Other significant complications include cerebrospinal fluid (CSF) leak, stroke and meningitis, present in 2.6, 2.2 and $0.4 \%$ of the cases respectively (Suarez et al. 2013a).

Other authors have suggested that the observation of VPGLs is associated with a better outcome: new CN palsy occurs in $7.5 \%$ of the cases (vs $60 \%$ postoperatively in the same series) and a $5 \%$ increase in size can be observed over 8.5 years (Bradshaw \& Jansen 2005). However, in this series, $75 \%$ were familial cases and over half asymptomatic (therefore possibly less advanced), although 2.5\% developed metastases during follow-up.

\section{JTPGLs}

Surgery is most challenging for JTPGLs as extensive exploration of the posterolateral skull base is required. In most studies, GTR has been achieved still in the majority of the cases (59-96\%) with 0-5\% mortality rate (no more than $2 \%$ in the most recent series), even for complex tumours. The GTR rate is generally lower in the Fisch C and D classes, and it decreases to $41 \%$ in class D tumours or $35 \%$ in those with a large intradural extension (Glassock et al. 1979, Jackson et al. 1990, Green et al. 1994, Gjuric et al. 1996, Briner et al. 1999, Moe et al. 1999, Forest et al. 2001, Tran Ba et al. 2001, Al-Mefty \& Teixeira 2002, Saringer et al. 2002, Pareschi et al. 2003, Suarez et al. 2007, Huy et al. 2009).

A meta-analysis published in 2011 has computed a pooled estimate of tumour control with GTR and subtotal resection (STR) of 86 and 69\% respectively (Ivan et al. 2011). In another review of the treatment results for JPGLs, the overall long-term tumour control irrespective of the degree of resection has been reported to be $78.2 \%$ with a $1.6 \%$ treatment-related mortality rate. The risk of recurrence after apparent GTR is $6.9 \%$ (Suarez et al. 2013a). However, in most surgical series, the follow-up duration is generally too short to allow all recurrences to be reported; with a longer follow-up duration (112 months), $18.8 \%$ can recur (Papaspyrou et al. 2009). The validity of pooling inhomogeneous data from different centres is questionable, but since large series are extremely rare, this approach offers some idea as to what to expect from surgery in these tumours.

The functional outcome following surgery is generally poor. At particular risk are the facial nerves (frequently mobilised in order to improve tumour exposure and removal) and hearing function. Immediate postoperative facial weakness is frequent, and long-term dysfunction is present in 14-33\% of the cases (Briner et al. 1999, Huy et al. 2009). Hearing function either remains stable or deteriorates; it is subjectively improved in only $6-16 \%$ of the cases, while 39\% may experience a deterioration (Glassock et al. 1979, Gjuric et al. 1996, Briner et al. 1999, Kunzel et al . 2012). Overall, up to $45.5 \%$ of the cases have some degree of hearing loss after surgery (Suarez et al. 2013a). The global risk of other postoperative $\mathrm{CN}$ deficits after GTR is also high: $38,26,40$ and $18 \%$ of the cases for nerves IX, X, XI and XII respectively (Ivan et al. 2011). Adjuvant procedures (e.g. tracheostomy, feeding tube, vocal cord medialisation procedure and gastrostomy) are used frequently, with at least one procedure being needed in up to $30 \%$ of the cases (Gottfried et al. 2004). However, because $\mathrm{CN}$ deficits are common preoperatively in JTPGLs and trigger obscure compensation mechanisms, long-term feeding tube dependence is equally frequent after CBT and JPGL surgery (Neskey et al. 2011). Overall, the risk of a new permanent deficit is still low in complex, very advanced JTPGLs, and a high GTR rate (85\%) can be achieved even in such cases (Al-Mefty \& Teixeira 2002).

Published by Bioscientifica Ltd. 
Normal activity after JTPGL surgery resumes slowly, being observed in $72 \%$ of the patients at 6 months and $97 \%$ after 1-2 years, reflecting the slow but progressive return of neurological function (Briner et al. 1999).

Other complications occur in $<10 \%$ of the patients (aspiration, infection and meningitis) with possibly higher rates for a CSF leak (11-14\%) (Moe et al. 1999, Al-Mefty \& Teixeira 2002, Lee et al. 2002, Gottfried et al. 2004, Kollert et al. 2006, Suarez et al. 2013a). In contrast to the risks for CBT surgery, the vascular risks are less significant, as these tumours mostly do not invade the carotids; the overall stroke rate is $1.6 \%$ (Gottfried et al. 2004). A rare but debilitating complication of JTPGL or VPGL surgery is the 'first bite syndrome', severe pain at the beginning of meal consumption (Netterville et al. 1998, Obholzer et al. 2011).

Tympanic PGLs are rarely reported separately; the results are generally more favourable, perhaps because they cause symptoms early and are diagnosed in less advanced stages. The GTR rate is $95-100 \%$ with $<8 \%$ of the cases with non-severe complications and a significantly lower duration of operation and hospital stay. Hearing is generally is maintained (Jackson et al. 1990, O'Leary et al. 1991).

\section{Radiotherapy}

Radiotherapeutic options include conventional fractionated EBRT and SRS.

EBRT has been largely studied for the treatment of HNPGLs and several advantages over surgery have been outlined. Partial/complete symptom relief in the months after treatment occurs in most (52-100\%) cases affected by tinnitus, dizziness/vertigo or pain. As opposed to surgery, a $\mathrm{CN}$ deficit present at diagnosis generally improves or remains stable (Cummings et al. 1984, de Jong et al. 1995, Huy et al. 2009).

Tumour control with radiotherapy is uniformly defined as a lack of tumour progression (although such an efficacy criterion in tumours with a natural slow growth is debatable); complete tumour remission is very rare, but a slow reduction of tumour volume occurs frequently. Local control occurs in $88-100 \%$ of the cases with variable follow-up durations (50 months- 11 years). The control rate decreases significantly with time: $95-96 \%$ at 5 years and $88-94 \%$ at 10 years, but only $73 \%$ at 25 years. Diseaserelated mortality after radiotherapy is low (0-5.1\%; Cummings et al. 1984, Hansen \& Thomsen 1988, Powell et al. 1992, Verniers et al. 1992, Hinerman et al. 2001, Chino et al. 2009, Huy et al. 2009, Lightowlers et al. 2010, Suarez et al. 2013a).
Mild complications (mucositis, nausea, xerostomia and otitis media/externa) occur occasionally, but are of limited significance (Cummings et al. 1984, Verniers et al. 1992, Hinerman et al. 2008). The most important concerns, especially in young patients, are those regarding serious late effects. Brain or bone necroses are serious adverse effects, albeit being rare nowadays ( 0.8 and $2.6 \%$ respectively; Suarez et al. 2013a). A literature analysis carried out in 1984 has reported brain necrosis to be present in $1.44 \%$ of the cases, all receiving higher doses (63-75 Gy; Cummings et al. 1984). Bone necrosis is also correlated with massive radiation doses or concurrent infection (Sharma et al. 1984). Currently, the usual dose is 45 Gy (Hinerman et al. 2008, Huy et al. 2009), and larger doses are no longer used, except for the treatment of malignant tumours, where the response is very poor even then (Hinerman et al. 2008, Moskovic et al. 2010). The radiation-induced malignancy rate is difficult to assess, due to the variable follow-up durations and inconsistency of its ascertainment. Aggressive bone osteosarcoma, fibrosarcoma (Lalwani et al. 1993, Mumber \& Greven 1995) and laryngeal carcinoma have been reported up to 25 years after treatment (Lack et al. 1977).

SRS has obvious advantages over EBRT (a single outpatient procedure and better anatomical targeting) and has been advocated as an alternative to surgery. Tumour control is achieved in larger series in $100 \%$ of the cases with $31-50 \%$ of the tumours slowly decreasing in size (decrease being variably defined). However, the median follow-up duration is short (2-4.8 years), so long-term true local control cannot be accurately assessed. Symptomatic improvement is frequent (29-70\%), and a new $\mathrm{CN}$ deficit or worsening of a pre-existing $\mathrm{CN}$ deficit occurs rarely (0-15\%) (Liscak et al. 1999, Foote et al. 2002, Pollock 2004, Lieberson et al. 2012). In a recent literature review, the overall control rate has been reported to be 98\% (mean follow-up duration of only 31 months) with a $3 \%$ overall complication rate (mostly mild: nausea, vomiting and vertigo) (Lieberson et al. 2012).

In skull base tumours (the most surgically challenging), SRS efficacy has also been reported favourably. A review of the literature published between 1994 and 2004 and a very recent one have reported similar results: a $32-37 \%$ decrease in size, $61 \%$ remaining stable over an average follow-up duration of 39-41 months. Neurological improvement occurs in $24-39 \%$ of the cases, and a few cases experience worsening of conditions (only 2.8\% permanent; Gottfried et al. 2004, Suarez et al. 2013a). However, new hearing loss is reported in up to $19 \%$ of the SRS-treated JPGL cases (probably due to bone radiation

Published by Bioscientifica Ltd. 
injury; Pollock 2004). JTPGL tumour control with SRS or EBRT is not statistically different, but the mortality due to disease or treatment has been reported to be significantly lower for SRS (Suarez et al. 2013a).

In a meta-analysis of treatment results for JPGLs, the tumour control rate for SRS with a long follow-up duration (mean 71 months) has been reported to be $95 \%$, better than that of GTR ( $86 \%$ at a mean duration of 88 months) (Ivan et al. 2011). This led the authors to conclude that SRS offers better control with a lower risk and should be preferred, reserving surgery for the debulking of larger tumours in preparation for SRS (STR followed by SRS in the same analysis controlled only $71 \%$ of the cases, probably due to selection bias). Despite these favourable comparisons, no robust evidence of superiority (e.g. in randomised control studies) exists. Follow-up after SRS is relatively short, so long-term control may be overestimated and the complication rate underestimated. As HNPGLs are generally slow growing (over $90 \%$ grow by $<0.5 \mathrm{~cm} /$ year; Langerman et al. 2012), a definitive assessment of longterm efficacy needs prolonged observation. In addition, the apparent lack of serious complications (e.g. secondary malignancies) needs long-term confirmation. Another limitation is that SRS can generally only be used successfully for the treatment of relatively small tumours (Foote et al. 2002, Chino et al. 2009), i.e. the most likely to be cured surgically without complications.

\section{Treatment of malignant HNPGLs}

Data from series of malignant HNPGLs are scarce. The outcome appears to be better with surgery and radiotherapy vs surgery alone. Younger patients tend to respond better, and the overall 5-year survival rate with complex therapy (surgery/radiotherapy/chemotherapy) may become $84 \%$ in young ( $<40$ years) patients (Lee et al. 2002, Moskovic et al. 2010).

The results of 'standard' chemotherapy are modest (Massey \& Wallner 1992, Patel et al. 1995, Pipas \& Krywicki 2000, Moskovic et al. 2010), in line with theoretical arguments against the efficacy of classic chemotherapy for slow-growing tumours. Somatostatin analogue (SSA) treatment for receptor-positive tumours has also not shown a major benefit (Duet et al. 2005). The use of modern anti-angiogenic therapies holds some promise, as PGLs are highly vascular tumours; sunitinib (a tyrosine kinase inhibitor) has shown some positive benefits in PGLs not based in the head and neck (Joshua et al. 2009).

PRRT with radiolabelled agents (MIBG or SSA) is an option for the treatment of malignant or inoperable PGLs with high uptake for the specific radiopharmaceutical - up to half of the cases show symptomatic and partial tumour response (Mukherjee et al. 2001, Van Essen et al. 2006, Gonias et al. 2009, Zovato et al. 2012). No studies have evaluated the possible efficacy of PRRT in earlier stages, on a more limited malignant tumour load (perhaps on lower doses that might decrease the risk of severe toxic reactions).

\section{Choice of therapy}

For the majority of tumours, complete cure is the most desirable outcome, and surgery is most likely to produce this outcome. However, for tumours with a more indolent natural history, it is important to minimise post-treatment morbidity, and thus therapies offering local control with fewer adverse effects, such as radiotherapy, can sometimes be preferable. Robust evidence in favour of any one treatment method cannot be easily obtained, as randomised trials are rare, current management strategies involve a selection bias, and success criteria have been very differently defined for surgery vs radiotherapy. Overall survival is similar to that of the general population (de Flines et al. 2011), albeit with reduced quality of life (Havekes et al. 2008), so this is not a useful end point for comparison. Therefore, the optimal management of HNPGLs has generated considerable debate over the years, and recommendations have varied from the routine use of radiotherapy (Verniers et al. 1992, Cole \& Beiler 1994) to simple observation for most patients (van der Mey et al. 1992).

In the light of current evidence, optimal management is highly dependent on the tumour (location, size, involvement of neurovascular structures, malignancy and hormone production), the patient (age, co-morbidities and symptoms) and the genetic status (implying potential for recurrence, malignancy or multicentric tumours). Pre-treatment assessment should include, where possible, a comprehensive $\mathrm{FH}$, detailed anatomical and functional imaging (to assess location, bone and vascular involvement, multicentricity, functional status, association with other tumours and distant metastases) and a genetic analysis (mutation carriers are younger, with higher rates of multicentricity and malignancy) (Burnichon et al. 2009), as well as an assessment of co-morbidities.

Surgery has been recommended as the treatment of choice in most patients, especially if performed at tertiary centres with surgeons having high expertise and the availability of a multidisciplinary team. As has been noted above, most CBTs (Sajid et al. 2007,

Published by Bioscientifica Ltd 
Makeieff et al. 2008), small, lower-cervical VPGLs (Urquhart et al. 1994), and class A and B temporal bone tumours (Moe et al. 1999, Suarez et al. 2007) can be cured surgically with an acceptable morbidity rate. Surgery is also the treatment of choice for all catecholamine-secreting PGLs (Young 2006). Advanced or skull base-located tumours are associated with the highest rate of complications and functional disability (with a low response to rehabilitation measures in the elderly). In such tumours, surgery is less effective and more likely to inflict serious damage (Moe et al. 1999, Pareschi et al. 2003). However, many complications are not permanent or do not significantly affect long-term function significantly (Briner et al. 1999). If an extensive $\mathrm{CN}$ deficit is present preoperatively, a radical procedure carries a low risk of additional neurological morbidity and offers a high chance of cure, even in advanced tumours (Al-Mefty \& Teixeira 2002). In younger (i.e. most) patients, rehabilitation for a surgery-inflicted neurological deficit is more likely to be reversible.

Primary radiotherapy has also been recommended for skull base tumours (Jackson et al. 1990), and recent evidence suggests that it might also be an option for the treatment of CBTs (Suarez et al. 2013b). Indeed, tumour growth arrest following radiotherapy is as frequent as surgical cure, while morbidity is significantly lower (Suarez et al. 2013a,b). Nevertheless, local control decreases with time, and salvage surgery after unsuccessful radiotherapy is technically difficult due to radiationinduced fibrosis. Radiotherapy carries a risk of severe late complications and the possibility of unrecognised malignant potential: irrespective of the type of radiotherapy used, viable cells persist and late distant spread can occur (Chino et al. 2009). In advanced cases, radiotherapy alone implies large-field irradiation with possible deleterious consequences. It would seem reasonable to particularly recommend radiotherapy for older patients, whose risk of late recurrence or complications might exceed life expectancy, and those with bilateral large tumours and/or contraindications to surgery (Moe et al. 1999, Suarez et al. 2007, Evans \& Collins 2008, Ma et al. 2009). While all types of radiotherapy may be effective, there appears to be an advantage for radiosurgery where this is technically possible.

For difficult surgical cases, STR followed by observation or radiotherapy is a reasonable approach, as debulking offers symptomatic improvement with a low morbidity rate (Cosetti et al. 2008) and facilitates the use of SRS on a smaller remnant. This conservative strategy has been reported to be successful in patients over 60 years of age (Cosetti et al. 2008), in those with advanced tumours
(Moe et al. 1999) or in individuals with previously normal CN function (Tran Ba et al. 2001). However, 'intended' STR is rarely described in the literature (frequently STR is the suboptimal result of an attempted total removal), so the theoretical benefit cannot be adequately assessed. Routine adjuvant radiotherapy has not been proven to improve the control rate (Ivan et al. 2011), so radiotherapy should probably be reserved for the treatment of postoperative remnant growth.

But is any intervention always required? Observation alone has been recommended, especially in the elderly and/or asymptomatic patients. (Lieberson et al. 2012). There are studies that have been carried out in The Netherlands showing overall normal life expectancy in HNPGL patients and no survival benefit irrespective of treatment (van der Mey et al. 1992, de Flines et al. 2011): these have been often cited to support observation as a major management strategy. However, simple observation may be inappropriate; if the tumour has malignant potential, unpredictable tumour-associated morbidity may occur, and if the tumour progresses, there may be a need for a later, more hazardous intervention. Watchful waiting can be used in patients deemed to have a short life expectancy (due to age or serious co-morbidities), but it may not be ideal for smaller tumours that may be readily resectable and that may progress or become invasive.

Multicentricity needs to be assessed as it increases the risk of debilitating bilateral neurological deficit (postoperatively and/or by mass effect). Unilateral surgery is usually performed (on the smallest tumour or the side with less $\mathrm{CN}$ palsies); contralateral surgery is performed only if no significant $\mathrm{CN}$ deficit has occurred. Otherwise, radiotherapy, STR or observation and may be appropriate action only if the tumour becomes symptomatic or grows (Al-Mefty \& Teixeira 2002). With genetic screening being more widely implemented, earlier discovery of multifocal tumours and improved treatment outcome are to be anticipated (Fruhmann et al. 2013).

For malignant tumours, surgery and adjuvant radiotherapy are offered for symptomatic relief and improved survival; systemic chemotherapy in unresectable disease and PRRT with radiolabelled agents in high-uptake tumours may be used in selected cases (Patel et al. 1995, Moskovic et al. 2010).

\section{Follow-up protocol}

In sporadic cases, annual head/neck MRI for the first 2 years (Papaspyrou et al. 2012) has been proposed.

Published by Bioscientifica Ltd 
However, the risk of recurrence persists many years after treatment, with a median time to recurrence of 5.8 years (average 8.2) (Jackson et al. 2001); this suggests that a more extended imaging follow-up might be cost beneficial, for at least the first 5 years after treatment. For sporadic CBTs, an annual neck ultrasound initially and then every 5 years has been suggested (Fruhmann et al. 2013), but clinical observation must be maintained indefinitely. Where functional, annual biochemical assessments are required for at least 10 years (Papaspyrou et al. 2012).

In familial cases, the exploration of carriers should begin a decade before the earliest age at diagnosis in the family (Young \& Abboud 2006). Annual clinical and biochemical assessments must be performed, with neck ultrasound, CT or MRI being performed every 1-2 years targeting mainly the locations most associated with the pathogenic mutation (Young \& Abboud 2006). SSR scintigraphy is also recommended as an adjunct to anatomical imaging for the initial evaluation and followup (Gimenez-Roqueplo et al. 2013), but there is no currently validated protocol for long-term follow-up. Where available, DOPA-PET can be used for whole-body screening during follow-up; it should be employed every 2-3 years or to confirm suspicious findings on CT/MRI (Boedeker et al. 2009a,b, Papaspyrou et al. 2012). In any protocol, familial cases should be monitored for multicentric disease indefinitely (Erickson et al. 2001).

\section{Conclusions}

The optimal treatment strategy for HNPGLs has not been defined yet. While surgery can be highly effective, it is not uncommonly associated with a high morbidity rate, while radiotherapeutic approaches can prevent tumour progression, but have uncertain long-term consequences. We would in general favour a conservative approach, accepting the need for intervention where there is evidence of tumour progression or where there is concern regarding malignancy. Where surgery is employed, it should generally be confined to smaller tumours in younger patients, while radiotherapy may play a larger role with more invasive or extensive tumours in older patients. A multidisciplinary team is always needed from diagnosis to treatment and follow-up (geneticists, radiologists, vascular surgeons, nuclear medicine specialists, rehabilitation specialists, oncologists, endocrinologists and speech therapists). Further progress in the understanding of PGL pathogenesis is likely to lead to earlier detection, which is essential for successful management.

\section{Declaration of interest}

The authors declare that there is no conflict of interest that could be perceived as prejudicing the impartiality of the review reported.

\section{Funding}

This review did not receive any specific grant from any funding agency in the public, commercial or not-for-profit sector.

\section{References}

Al-Mefty O \& Teixeira A 2002 Complex tumors of the glomus jugulare: criteria, treatment, and outcome. Journal of Neurosurgery 97 1356-1366. (doi:10.3171/jns.2002.97.6.1356)

Anand VK, Alemar GO \& Sanders TS 1995 Management of the internal carotid artery during carotid body tumor surgery. Laryngoscope $\mathbf{1 0 5}$ 231-235. (doi:10.1288/00005537-199503000-00001)

Astuti D, Latif F, Dallol A, Dahia PL, Douglas F, George E, Skoldberg F, Husebye ES, Eng C \& Maher ER 2001 Gene mutations in the succinate dehydrogenase subunit SDHB cause susceptibility to familial pheochromocytoma and to familial paraganglioma. American Journal of Human Genetics 69 49-54. (doi:10.1086/321282)

Barnes L, Tse LLY, Hunt JL \& Michaels L 2004 Tumours of the paraganglionic system WHO Classification of Tumours, Volume 8 IARC WHO Classification of Tumours. Geneva: WHO press.

Bayley JP, Kunst HP, Cascon A, Sampietro ML, Gaal J, Korpershoek E, Hinojar-Gutierrez A, Timmers HJ, Hoefsloot LH, Hermsen MA et al. 2010 SDHAF2 mutations in familial and sporadic paraganglioma and phaeochromocytoma. Lancet Oncology 11 366-372. (doi:10.1016/ S1470-2045(10)70007-3)

Baysal BE 2002 Hereditary paraganglioma targets diverse paraganglia. Journal of Medical Genetics 39 617-622. (doi:10.1136/jmg.39.9.617)

Baysal BE, Ferrell RE, Willett-Brozick JE, Lawrence EC, Myssiorek D, Bosch A, van der Mey A, Taschner PE, Rubinstein WS, Myers EN et al. 2000 Mutations in SDHD, a mitochondrial complex II gene, in hereditary paraganglioma. Science 287 848-851. (doi:10.1126/ science.287.5454.848)

Benn DE, Gimenez-Roqueplo AP, Reilly JR, Bertherat J, Burgess J, Byth K, Croxson M, Dahia PL, Elston M, Gimm O et al. 2006 Clinical presentation and penetrance of pheochromocytoma/paraganglioma syndromes. Journal of Clinical Endocrinology and Metabolism 91 827-836. (doi:10.1210/jc.2005-1862)

van den Berg R, Wasser MN, van Gils AP, van der Mey AG, Hermans J \& van Buchem MA 2000 Vascularization of head and neck paragangliomas: comparison of three MR angiographic techniques with digital subtraction angiography. AJNR. American Journal of Neuroradiology 21 162-170.

Blanchet EM, Martucci V \& Pacak K 2011 Pheochromocytoma and paraganglioma: current functional and future molecular imaging. Frontiers in Oncology 1 58. (doi:10.3389/fonc.2011.00058)

Boedeker CC, Erlic Z, Richard S, Kontny U, Gimenez-Roqueplo AP, Cascon A, Robledo M, de Campos JM, van Nederveen FH, de Krijger RR et al. $2009 a$ Head and neck paragangliomas in von Hippel-Lindau disease and multiple endocrine neoplasia type 2. Journal of Clinical Endocrinology and Metabolism 94 1938-1944. (doi:10.1210/ jc.2009-0354)

Boedeker CC, Neumann HP, Offergeld C, Maier W, Falcioni M, Berlis A \& Schipper J 2009b Clinical features of paraganglioma syndromes. Skull Base 19 17-25. (doi:10.1055/s-0028-1103123)

Bradshaw JW \& Jansen JC 2005 Management of vagal paraganglioma: is operative resection really the best option? Surgery 137 225-228. (doi:10.1016/j.surg.2004.09.009) http://erc.endocrinology-journals.org DOI: 10.1530/ERC-13-0223 (c) 2013 Society for Endocrinology Printed in Great Britain 
Briner HR, Linder TE, Pauw B \& Fisch U 1999 Long-term results of surgery for temporal bone paragangliomas. Laryngoscope 109 577-583. (doi:10.1097/00005537-199904000-00011)

Burnichon N, Rohmer V, Amar L, Herman P, Leboulleux S, Darrouzet V, Niccoli P, Gaillard D, Chabrier G, Chabolle F et al. 2009 The succinate dehydrogenase genetic testing in a large prospective series of patients with paragangliomas. Journal of Clinical Endocrinology and Metabolism 94 2817-2827. (doi:10.1210/jc.2008-2504)

Carney JA, Sheps SG, Go VL \& Gordon H 1977 The triad of gastric leiomyosarcoma, functioning extra-adrenal paraganglioma and pulmonary chondroma. New England Journal of Medicine 296 1517-1518. (doi:10.1056/NEJM197706302962609)

Cascon A, Lopez-Jimenez E, Landa I, Leskela S, Leandro-Garcia LJ, Maliszewska A, Leton R, de la Vega L, Garcia-Barcina MJ, Sanabria C et al. 2009 Rationalization of genetic testing in patients with apparently sporadic pheochromocytoma/paraganglioma. Hormone and Metabolic Research 41 672-675. (doi:10.1055/s-0029-1202814)

Chino JP, Sampson JH, Tucci DL, Brizel DM \& Kirkpatrick JP 2009 Paraganglioma of the head and neck: long-term local control with radiotherapy. American Journal of Clinical Oncology 32 304-307. (doi:10.1097/COC.0b013e318187dd94)

Cole JM \& Beiler D 1994 Long-term results of treatment for glomus jugulare and glomus vagale tumors with radiotherapy. Laryngoscope $\mathbf{1 0 4}$ 1461-1465. (doi:10.1288/00005537-199412000-00006)

Cosetti M, Linstrom C, Alexiades G, Tessema B \& Parisier S 2008 Glomus tumors in patients of advanced age: a conservative approach. Laryngoscope 118 270-274. (doi:10.1097/MLG.0b013e318158194b)

Cummings BJ, Beale FA, Garrett PG, Harwood AR, Keane TJ, Payne DG \& Rider WD 1984 The treatment of glomus tumors in the temporal bone by megavoltage radiation. Cancer 53 2635-2640. (doi:10.1002/10970142(19840615)53:12<2635::AID-CNCR2820531211>3.0.CO;2-9)

DeAngelis LM, Kelleher MB, Post KD \& Fetell MR 1987 Multiple paragangliomas in neurofibromatosis: a new neuroendocrine neoplasia. Neurology 37 129-133. (doi:10.1212/WNL.37.1.129)

De Toma G, Nicolanti V, Plocco M, Cavallaro G, Letizia C, Piccirillo G \& Cavallaro A 2000 Baroreflex failure syndrome after bilateral excision of carotid body tumors: an underestimated problem. Journal of Vascular Surgery 31 806-810. (doi:10.1067/mva.2000.103789)

Duet M, Guichard JP, Rizzo N, Boudiaf M, Herman P \& Tran Ba HP 2005 Are somatostatin analogs therapeutic alternatives in the management of head and neck paragangliomas? Laryngoscope 115 1381-1384. (doi:10.1097/01.MLG.0000165806.99675.A9)

van Duinen N, Steenvoorden D, Kema IP, Jansen JC, Vriends AH, Bayley JP, Smit JW, Romijn JA \& Corssmit EP 2010 Increased urinary excretion of 3-methoxytyramine in patients with head and neck paragangliomas. Journal of Clinical Endocrinology and Metabolism 95 209-214. (doi:10.1210/jc.2009-1632)

van Duinen N, Kema IP, Romijn JA \& Corssmit EP 2011 Plasma chromogranin A levels are increased in a small portion of patients with hereditary head and neck paragangliomas. Clinical Endocrinology $\mathbf{7 4}$ 160-165. (doi:10.1111/j.1365-2265.2010.03914.x)

Eisenhofer G, Goldstein DS, Sullivan P, Csako G, Brouwers FM, Lai EW, Adams KT \& Pacak K 2005 Biochemical and clinical manifestations of dopamine-producing paragangliomas: utility of plasma methoxytyramine. Journal of Clinical Endocrinology and Metabolism 90 2068-2075. (doi:10.1210/jc.2004-2025)

Erickson D, Kudva YC, Ebersold MJ, Thompson GB, Grant CS, van Heerden JA \& Young WF Jr 2001 Benign paragangliomas: clinical presentation and treatment outcomes in 236 patients. Journal of Clinical Endocrinology and Metabolism 86 5210-5216. (doi:10.1210/ jc.86.11.5210)

Evans JM \& Collins M 2008 Clinically diagnosed glomus vagale tumour treated with external beam radiotherapy: a review of the published reports. Journal of Medical Imaging and Radiation Oncology 52 617-621. (doi:10.1111/j.1440-1673.2008.01941.x)
Fisch U \& Mattox DE 1988 Infratemporal fossa approach type A. Classification of glomus temporale tumours. In Microsurgery of the skull base, pp136-152. Stuttgart, Germany: Thieme.

de Flines J, Jansen J, Elders R, Siemers M, Vriends A, Hes F, Bayley JP, van der Mey A \& Corssmit E 2011 Normal life expectancy for paraganglioma patients: a 50-year-old cohort revisited. Skull Base 21 385-388. (doi:10.1055/s-0031-1287681)

Foote RL, Pollock BE, Gorman DA, Schomberg PJ, Stafford SL, Link MJ, Kline RW, Strome SE, Kasperbauer JL \& Olsen KD 2002 Glomus jugulare tumor: tumor control and complications after stereotactic radiosurgery. Head \& Neck 24 332-338. (doi:10.1002/hed.10005)

Forest JA III, Jackson CG \& McGrew BM 2001 Long-term control of surgically treated glomus tympanicum tumors. Otology \& Neurotology 22 232-236. (doi:10.1097/00129492-200103000-00020)

Fruhmann J, Geigl JB, Konstantiniuk P \& Cohnert TU 2013 Paraganglioma of the carotid body: treatment strategy and SDH-gene mutations. European Journal of Vascular and Endovascular Surgery 45 431-436. (doi:10.1016/j.ejvs.2013.01.018)

Gaal J, van Nederveen FH, Erlic Z, Korpershoek E, Oldenburg R, Boedeker CC, Kontny U, Neumann HP, Dinjens WN \& de Krijger RR 2009 Parasympathetic paragangliomas are part of the Von Hippel-Lindau syndrome. Journal of Clinical Endocrinology and Metabolism 94 4367-4371. (doi:10.1210/jc.2009-1479)

Gabriel S, Blanchet EM, Sebag F, Chen CC, Fakhry N, Deveze A, Barlier A, Morange I, Pacak K \& Taieb D 2013 Functional characterization of nonmetastatic paraganglioma and pheochromocytoma by (18) F-FDOPA PET: focus on missed lesions. Clinical Endocrinology 79 170-177. (doi:10.1111/cen.12126)

Gaylis H, Davidge-Pitts K \& Pantanowitz D 1987 Carotid body tumours. A review of 52 cases. South African Medical Journal 72 493-496.

Gimenez-Roqueplo AP, Dahia PL \& Robledo M 2012 An update on the genetics of paraganglioma, pheochromocytoma, and associated hereditary syndromes. Hormone and Metabolic Research 44 328-333. (doi:10.1055/s-0031-1301302)

Gimenez-Roqueplo AP, Caumont-Prim A, Houzard C, Hignette C, Hernigou A, Halimi P, Niccoli P, Leboulleux S, Amar L, Borson-Chazot F et al. 2013 Imaging work-up for screening of paraganglioma and pheochromocytoma in SDHx mutation carriers: a multicenter prospective study from the PGL.EVA Investigators. Journal of Clinical Endocrinology and Metabolism 98 E162-E173. (doi:10.1210/ jc.2012-2975)

Gjuric M, Seidinger L \& Wigand ME 1996 Long-term results of surgery for temporal bone paraganglioma. Skull Base Surgery 6 147-152. (doi:10.1055/s-2008-1058638)

Glassock ME III, Jackson CG, Dickins JR \& Wiet RJ 1979 Panel discussion: glomus jugulare tumors of the temporal bone. The surgical management of glomus tumors. Laryngoscope 89 1640-1654. (doi:10.1002/lary. 5540891015)

Gonias S, Goldsby R, Matthay KK, Hawkins R, Price D, Huberty J, Damon L, Linker C, Sznewajs A, Shiboski S et al. 2009 Phase II study of high-dose [131I] metaiodobenzylguanidine therapy for patients with metastatic pheochromocytoma and paraganglioma. Journal of Clinical Oncology 27 4162-4168. (doi:10.1200/JCO.2008.21.3496)

Gottfried ON, Liu JK \& Couldwell WT 2004 Comparison of radiosurgery and conventional surgery for the treatment of glomus jugulare tumors. Neurosurgical Focus 17 E4.

Green JD Jr, Brackmann DE, Nguyen CD, Arriaga MA, Telischi FF \& de la Cruz A 1994 Surgical management of previously untreated glomus jugulare tumors. Laryngoscope 104 917-921. (doi:10.1288/00005537199408000-00001)

Hansen HS \& Thomsen KA 1988 Radiotherapy in glomus tumours (paragangliomas). A 25 year-review. Acta Oto-Laryngologica. Supplementum 449 151-154. (doi:10.3109/00016488809106399)

Hao HX, Khalimonchuk O, Schraders M, Dephoure N, Bayley JP, Kunst H, Devilee P, Cremers CW, Schiffman JD, Bentz BG et al. 2009 SDH5, a 
gene required for flavination of succinate dehydrogenase, is mutated in paraganglioma. Science 325 1139-1142. (doi:10.1126/science.1175689)

Havekes B, van der Klaauw AA, Hoftijzer HC, Jansen JC, van der Mey AG, Vriends AH, Smit JW, Romijn JA \& Corssmit EP 2008 Reduced quality of life in patients with head-and-neck paragangliomas. European Journal of Endocrinology 158 247-253. (doi:10.1530/EJE-07-0464)

Hensen EF, Siemers MD, Jansen JC, Corssmit EP, Romijn JA, Tops CM, van der Mey AG, Devilee P, Cornelisse CJ, Bayley JP et al. 2011 Mutations in SDHD are the major determinants of the clinical characteristics of Dutch head and neck paraganglioma patients. Clinical Endocrinology 75 650-655. (doi:10.1111/j.1365-2265.2011.04097.x)

Hinerman RW, Mendenhall WM, Amdur RJ, Stringer SP, Antonelli PJ \& Cassisi NJ 2001 Definitive radiotherapy in the management of chemodectomas arising in the temporal bone, carotid body, and glomus vagale. Head \& Neck 23 363-371. (doi:10.1002/hed.1045)

Hinerman RW, Amdur RJ, Morris CG, Kirwan J, Mendenhall WM \& Stringer SP 2008 Definitive radiotherapy in the management of paragangliomas arising in the head and neck: a 35-year experience. Head \& Neck 30 1431-1438.

Huy PT, Kania R, Duet M, Dessard-Diana B, Mazeron JJ \& Benhamed R 2009 Evolving concepts in the management of jugular paraganglioma: a comparison of radiotherapy and surgery in 88 cases. Skull Base $\mathbf{1 9}$ 83-91. (doi:10.1055/s-0028-1103125)

Ivan ME, Sughrue ME, Clark AJ, Kane AJ, Aranda D, Barani IJ \& Parsa AT 2011 A meta-analysis of tumor control rates and treatment-related morbidity for patients with glomus jugulare tumors. Journal of Neurosurgery 114 1299-1305. (doi:10.3171/2010.9.JNS10699)

Jackson CG, Harris PF, Glasscock ME III, Fritsch M, Dimitrov E, Johnson GD \& Poe DS 1990 Diagnosis and management of paragangliomas of the skull base. American Journal of Surgery 159 389-393. (doi:10.1016/ S0002-9610(05)81279-6)

Jackson CG, McGrew BM, Forest JA, Netterville JL, Hampf CF \& Glasscock ME III 2001 Lateral skull base surgery for glomus tumors: long-term control. Otology \& Neurotology 22 377-382. (doi:10.1097/00129492200105000-00018)

Jafri M, Whitworth J, Rattenberry E, Bradley L, Kilby G, Kumar AV, Izatt L, Lalloo F, Brennan P, Cook J et al. 2013 Evaluation of SDHB, SDHD and VHL gene susceptibility testing in the assessment of individuals with non-syndromic phaeochromocytoma and paraganglioma and head and neck paraganglioma (HNPGL). Clinical Endocrinology 78 898-906. (doi:10.1111/cen.12074)

Jansen JC, van den Berg R, Kuiper A, van der Mey AG, Zwinderman AH \& Cornelisse CJ 2000 Estimation of growth rate in patients with head and neck paragangliomas influences the treatment proposal. Cancer $\mathbf{8 8}$ 2811-2816. (doi:10.1002/1097-0142(20000615)88:12<2811::AIDCNCR21>3.0.CO;2-7)

de Jong AL, Coker NJ, Jenkins HA, Goepfert H \& Alford BR 1995 Radiation therapy in the management of paragangliomas of the temporal bone. American Journal of Otology 16 283-289. (doi:10.1016/01960709(95)90054-3)

Joshua AM, Ezzat S, Asa SL, Evans A, Broom R, Freeman M \& Knox JJ 2009 Rationale and evidence for sunitinib in the treatment of malignant paraganglioma/pheochromocytoma. Journal of Clinical Endocrinology and Metabolism 94 5-9. (doi:10.1210/jc.2008-1836)

Kahn LB 1976 Vagal body tumor (nonchromaffin paraganglioma, chemodectoma, and carotid body-like tumor) with cervical node metastasis and familial association: ultrastructural study and review. Cancer 38 2367-2377. (doi:10.1002/1097-0142(197612)38:6< 2367::AID-CNCR2820380625>3.0.CO;2-3)

King KS, Chen CC, Alexopoulos DK, Whatley MA, Reynolds JC, Patronas N, Ling A, Adams KT, Xekouki P, Lando H et al. 2011 Functional imaging of SDHx-related head and neck paragangliomas: comparison of 18F-fluorodihydroxyphenylalanine, 18F-fluorodopamine, 18F-fluoro2-deoxy-D-glucose PET, 123I-metaiodobenzylguanidine scintigraphy, and 111In-pentetreotide scintigraphy. Journal of Clinical Endocrinology and Metabolism 96 2779-2785. (doi:10.1210/jc.2011-0333)
Kloppel G 2003 Tumors of the adrenal medulla and the paraganglia. Der Pathologe 24 280-286. (doi:10.1007/s00292-003-0635-8)

Kohler HF, Carvalho AL, Mattos Granja NV, Nishinari K \& Kowalski LP 2004 Surgical treatment of paragangliomas of the carotid bifurcation: results of 36 patients. Head \& Neck 26 1058-1063. (doi:10.1002/hed. 20105)

Kollert M, Minovi AA, Draf W \& Bockmuhl U 2006 Cervical paragangliomastumor control and long-term functional results after surgery. Skull Base 16 185-191. (doi:10.1055/s-2006-950386)

Korevaar TI \& Grossman AB 2011 Pheochromocytomas and paragangliomas: assessment of malignant potential. Endocrine 40 354-365. (doi:10.1007/s12020-011-9545-3)

Kunst HP, Rutten MH, de Monnink JP, Hoefsloot LH, Timmers HJ, Marres HA, Jansen JC, Kremer H, Bayley JP \& Cremers CW 2011 SDHAF2 (PGL2-SDH5) and hereditary head and neck paraganglioma. Clinical Cancer Research 17 247-254. (doi:10.1158/1078-0432.CCR10-0420)

Kunzel J, Iro H, Hornung J, Koch M, Brase C, Klautke G \& Zenk J 2012 Function-preserving therapy for jugulotympanic paragangliomas: a retrospective analysis from 2000 to 2010. Laryngoscope $\mathbf{1 2 2}$ 1545-1551. (doi:10.1002/lary.23268)

Lack EE, Cubilla AL, Woodruff JM \& Farr HW 1977 Paragangliomas of the head and neck region: a clinical study of 69 patients. Cancer 39 397-409. (doi:10.1002/1097-0142(197702)39:2<397::AIDCNCR2820390205>3.0.CO;2-C)

Lalwani AK, Jackler RK \& Gutin PH 1993 Lethal fibrosarcoma complicating radiation therapy for benign glomus jugulare tumor. American Journal of Otology 14 398-402.

Langerman A, Athavale SM, Rangarajan SV, Sinard RJ \& Netterville JL 2012 Natural history of cervical paragangliomas: outcomes of observation of 43 patients. Archives of Otolaryngology - Head \& Neck Surgery 138 341-345. (doi:10.1001/archoto.2012.37)

Lee JH, Barich F, Karnell LH, Robinson RA, Zhen WK, Gantz BJ \& Hoffman HT 2002 National Cancer Data Base report on malignant paragangliomas of the head and neck. Cancer 94 730-737. (doi:10.1002/cncr.10252)

Lees CD, Levine HL, Beven EG \& Tucker HM 1981 Tumors of the carotid body. Experience with 41 operative cases. American Journal of Surgery 142 362-365. (doi:10.1016/0002-9610(81)90349-4)

Lieberson RE, Adler JR, Soltys SG, Choi C, Gibbs IC \& Chang SD 2012 Stereotactic radiosurgery as the primary treatment for new and recurrent paragangliomas: is open surgical resection still the treatment of choice? World Neurosurgery 77 745-761. (doi:10.1016/j.wneu.2011. 03.026)

Lightowlers S, Benedict S, Jefferies SJ, Jena R, Harris F, Burton KE \& Burnet NG 2010 Excellent local control of paraganglioma in the head and neck with fractionated radiotherapy. Clinical Oncology 22 382-389. (doi:10.1016/j.clon.2010.02.006)

Liscak R, Vladyka V, Wowra B, Kemeny A, Forster D, Burzaco JA, Martinez R, Eustacchio S, Pendl G, Regis J et al. 1999 Gamma knife radiosurgery of the glomus jugulare tumour - early multicentre experience. Acta Neurochirurgica 141 1141-1146. (doi:10.1007/s007010050411)

Lozano FS, Gomez JL, Mondillo MC, Gonzalez-Porras JR, GonzalezSarmiento R \& Munoz A 2008 Surgery of vagal paragangliomas: six patients and review of literature. Surgical Oncology 17 281-287.

Luna-Ortiz K, Rascon-Ortiz M, Villavicencio-Valencia V, Granados-Garcia M \& Herrera-Gomez A 2005 Carotid body tumors: review of a 20-year experience. Oral Oncology 41 56-61. (doi:10.1016/j.oraloncology.2004. 06.006)

Ma D, Liu L, Yao H, Hu Y, Ji T, Liu X, Zhang C \& Qiu W 2009 A retrospective study in management of carotid body tumour. British Journal of Oral \& Maxillofacial Surgery 47 461-465. (doi:10.1016/j.bjoms.2009.06.006)

Makeieff M, Raingeard I, Alric P, Bonafe A, Guerrier B \& Marty-Ane C 2008 Surgical management of carotid body tumors. Annals of Surgical Oncology 15 2180-2186. (doi:10.1245/s10434-008-9977-z) 
Manolidis S, Shohet JA, Jackson CG \& Glasscock ME III 1999 Malignant glomus tumors. Laryngoscope 109 30-34. (doi:10.1097/00005537199901000-00007)

Massey V \& Wallner K 1992 Treatment of metastatic chemodectoma. Cancer 69 790-792. (doi:10.1002/1097-0142(19920201)69:3<790: AID-CNCR2820690329>3.0.CO;2-U)

van der Mey AG, Frijns JH, Cornelisse CJ, Brons EN, van Dulken H, Terpstra HL \& Schmidt PH 1992 Does intervention improve the natural course of glomus tumors? A series of 108 patients seen in a 32-year period Annals of Otology, Rhinology, and Laryngology 101 635-642.

Miller RB, Boon MS, Atkins JP \& Lowry LD 2000 Vagal paraganglioma: the Jefferson experience. Otolaryngology-Head and Neck Surgery 122 482-487.

Moe KS, Li D, Linder TE, Schmid S \& Fisch U 1999 An update on the surgical treatment of temporal bone paraganglioma. Skull Base Surgery 9 185-194. (doi:10.1055/s-2008-1058145)

Moskovic DJ, Smolarz JR, Stanley D, Jimenez C, Williams MD, Hanna EY \& Kupferman ME 2010 Malignant head and neck paragangliomas: is there an optimal treatment strategy? Head \& Neck Oncology 223. (doi:10.1186/1758-3284-2-23)

Mukherjee JJ, Kaltsas GA, Islam N, Plowman PN, Foley R, Hikmat J, Britton KE, Jenkins PJ, Chew SL, Monson JP et al. 2001 Treatment of metastatic carcinoid tumours, phaeochromocytoma, paraganglioma and medullary carcinoma of the thyroid with (131)I-meta-iodobenzylguanidine [(131)I-mIBG]. Clinical Endocrinology 55 47-60. (doi:10.1046/j.1365-2265.2001.01309.x)

Mumber MP \& Greven KM 1995 Control of advanced chemodectomas of the head and neck with irradiation. American Journal of Clinical Oncology 18 389-391. (doi:10.1097/00000421-199510000-00005)

van Nederveen FH, Gaal J, Favier J, Korpershoek E, Oldenburg RA, de Bruyn EM, Sleddens HF, Derkx P, Riviere J, Dannenberg H et al. 2009 An immunohistochemical procedure to detect patients with paraganglioma and phaeochromocytoma with germline SDHB, SDHC, or SDHD gene mutations: a retrospective and prospective analysis. Lancet Oncology 10 764-771. (doi:10.1016/S1470-2045(09)70164-0)

Neskey DM, Hatoum G, Modh R, Civantos F, Telischi FF, Angeli SI, Weed D \& Sargi Z 2011 Outcomes after surgical resection of head and neck paragangliomas: a review of 61 patients. Skull Base 21 171-176. (doi:10.1055/s-0031-1275251)

Netterville JL \& Civantos FJ 1993 Rehabilitation of cranial nerve deficits after neurotologic skull base surgery. Laryngoscope 103 45-54.

Netterville JL, Jackson CG, Miller FR, Wanamaker JR \& Glasscock ME 1998 Vagal paraganglioma: a review of 46 patients treated during a 20-year period. Archives of Otolaryngology - Head \& Neck Surgery 124 1133-1140. (doi:10.1001/archotol.124.10.1133)

Neumann HP, Erlic Z, Boedeker CC, Rybicki LA, Robledo M, Hermsen M, Schiavi F, Falcioni M, Kwok P, Bauters C et al. 2009 Clinical predictors for germline mutations in head and neck paraganglioma patients: cost reduction strategy in genetic diagnostic process as fall-out. Cancer Research 69 3650-3656. (doi:10.1158/0008-5472.CAN-08-4057)

Niemann S, Steinberger D \& Muller U 1999 PGL3, a third, not maternally imprinted locus in autosomal dominant paraganglioma. Neurogenetics 2 167-170. (doi:10.1007/s100480050078)

Obholzer RJ, Hornigold R, Connor S \& Gleeson MJ 2011 Classification and management of cervical paragangliomas. Annals of the Royal College of Surgeons of England 93 596-602. (doi:10.1308/ 147870811X13137608455172)

Offergeld C, Brase C, Yaremchuk S, Mader I, Rischke HC, Glasker S, Schmid KW, Wiech T, Preuss SF, Suarez C et al. 2012 Head and neck paragangliomas: clinical and molecular genetic classification. Clinics 67 (Suppl 1) 19-28. (doi:10.6061/clinics/2012(Sup01)05)

O'Leary MJ, Shelton C, Giddings NA, Kwartler J \& Brackmann DE 1991 Glomus tympanicum tumors: a clinical perspective. Laryngoscope $\mathbf{1 0 1}$ 1038-1043. (doi:10.1002/lary.5541011213)

Papaspyrou K, Mann WJ \& Amedee RG 2009 Management of head and neck paragangliomas: review of 120 patients. Head \& Neck 31 381-387. (doi:10.1002/hed.20967)
Papaspyrou K, Mewes T, Rossmann H, Fottner C, Schneider-Raetzke B, Bartsch O, Schreckenberger M, Lackner KJ, Amedee RG \& Mann WJ 2012 Head and neck paragangliomas: report of 175 patients (1989-2010). Head \& Neck 34 632-637. (doi:10.1002/hed.21790)

Pareschi R, Righini S, Destito D, Raucci AF \& Colombo S 2003 Surgery of glomus jugulare tumors. Skull Base 13 149-157. (doi:10.1055/s-2003-43325)

Paris J, Facon F, Thomassin JM \& Zanaret M 2006 Cervical paragangliomas: neurovascular surgical risk and therapeutic management. European Archives of Oto-Rhino-Laryngology 263 860-865. (doi:10.1007/s00405006-0074-2)

Patel SR, Winchester DJ \& Benjamin RS 1995 A 15-year experience with chemotherapy of patients with paraganglioma. Cancer 76 1476-1480. (doi:10.1002/1097-0142(19951015)76:8 < 1476::AID-CNCR2820 760827 > 3.0.CO;2-9)

Patetsios P, Gable DR, Garrett WV, Lamont JP, Kuhn JA, Shutze WP, Kourlis H, Grimsley B, Pearl GJ, Smith BL et al. 2002 Management of carotid body paragangliomas and review of a 30-year experience. Annals of Vascular Surgery 16 331-338. (doi:10.1007/s10016-0010106-8)

Persky MS, Setton A, Niimi Y, Hartman J, Frank D \& Berenstein A 2002 Combined endovascular and surgical treatment of head and neck paragangliomas - a team approach. Head \& Neck 24 423-431. (doi:10.1002/hed.10068)

Pipas JM \& Krywicki RF 2000 Treatment of progressive metastatic glomus jugulare tumor (paraganglioma) with gemcitabine. Neuro-Oncology 2 190-191.

Plukker JT, Brongers EP, Vermey A, Krikke A \& van den Dungen JJ 2001 Outcome of surgical treatment for carotid body paraganglioma. British Journal of Surgery $\mathbf{8 8}$ 1382-1386. (doi:10.1046/j.0007-1323. 2001.01878.x)

Pollock BE 2004 Stereotactic radiosurgery in patients with glomus jugulare tumors. Neurosurgical Focus 17 E10. (doi:10.3171/foc.2004.17.2.10)

Powell S, Peters N \& Harmer C 1992 Chemodectoma of the head and neck: results of treatment in 84 patients. International Journal of Radiation Oncology, Biology, Physics 22 919-924. (doi:10.1016/03603016(92) $90788-\mathrm{J})$

Rao AB, Koeller KK \& Adair CF 1999 From the archives of the AFIP. Paragangliomas of the head and neck: radiologic-pathologic correlation. 1999 Armed Forces Institute of Pathology. Radiographics 19 1605-1632.

Rodriguez-Cuevas S, Lopez-Garza J \& Labastida-Almendaro S 1998 Carotid body tumors in inhabitants of altitudes higher than 2000 meters above sea level. Head \& Neck 20 374-378. (doi:10.1002/(SICI)10970347(199808) 20:5 < 374::AID-HED3 > 3.0.CO;2-V)

Sajid MS, Hamilton G \& Baker DM 2007 A multicenter review of carotid body tumour management. European Journal of Vascular and Endovascular Surgery 34 127-130. (doi:10.1016/j.ejvs.2007.01.015)

Saringer W, Kitz K, Czerny C, Kornfehl J, Gstottner W, Matula C \& Knosp E 2002 Paragangliomas of the temporal bone: results of different treatment modalities in 53 patients. Acta Neurochirurgica 144 1255-1264. (doi:10.1007/s00701-002-1016-4)

Sevilla Garcia MA, Llorente Pendas JL, Rodrigo Tapia JP, Garcia RG, Surez FV, Coca PA \& Surez NC 2007 Head and neck paragangliomas: revision of 89 cases in 73 patients. Acta Otorrinolaringológica Española 58 94-100. (doi:10.1016/S0001-6519(07)74888-4)

Shamblin WR, ReMine WH, Sheps SG \& Harrison EG Jr 1971 Carotid body tumor (chemodectoma). Clinicopathologic analysis of ninety cases. American Journal of Surgery 122 732-739. (doi:10.1016/00029610(71)90436-3)

Sharma PD, Johnson AP \& Whitton AC 1984 Radiotherapy for jugulo-tympanic paragangliomas (glomus jugulare tumours). Journal of Laryngology and Otology 98 621-629. (doi:10.1017/ S0022215100147188)

Sharma P, Thakar A, Suman KS, Dhull VS, Singh H, Naswa N, Reddy RM, Karunanithi S, Kumar R \& Kumar R 2013 68Ga-DOTANOC PET/CT for baseline evaluation of patients with head and neck paraganglioma. 
Journal of Nuclear Medicine 54 841-847. (doi:10.2967/jnumed.112. 115485)

Smith JJ, Passman MA, Dattilo JB, Guzman RJ, Naslund TC \& Netterville JL 2006 Carotid body tumor resection: does the need for vascular reconstruction worsen outcome? Annals of Vascular Surgery 20 435-439. (doi:10.1007/s10016-006-9093-0)

Suarez C, Sevilla MA \& Llorente JL 2007 Temporal paragangliomas. European Archives of Oto-Rhino-Laryngology 264 719-731. (doi:10.1007/ s00405-007-0267-3)

Suarez C, Rodrigo JP, Bodeker CC, Llorente JL, Silver CE, Jansen JC, Takes RP, Strojan P, Pellitteri PK, Rinaldo A et al. 2013a Jugular and vagal paragangliomas: systematic study of management with surgery and radiotherapy. Head \& Neck 35 1195-1204. (doi:10.1002/hed.22976)

Suarez C, Rodrigo JP, Mendenhall WM, Hamoir M, Silver CE, Gregoire V, Strojan P, Neumann HP, Obholzer R \& Offergeld C 2013b Carotid body paragangliomas: a systematic study of management with surgery and radiotherapy. European Archives of Oto-Rhino-Laryngology [in press]. (doi:10.1007/s00405-013-2384-5)

Timmers HJ, Karemaker JM, Wieling W, Marres HA, Folgering HT \& Lenders LW 2003 Baroreflex and chemoreflex function after bilateral carotid body tumor resection. Journal of Hypertension 21 591-599. (doi:10.1097/00004872-200303000-00026)

Timmers HJ, Chen CC, Carrasquillo JA, Whatley M, Ling A, Havekes B, Eisenhofer G, Martiniova L, Adams KT \& Pacak K 2009 Comparison of 18F-fluoro-L-DOPA, 18F-fluoro-deoxyglucose, and 18F-fluorodopamine PET and 123I-MIBG scintigraphy in the localization of pheochromocytoma and paraganglioma. Journal of Clinical Endocrinology and Metabolism 94 4757-4767. (doi:10.1210/jc.2009-1248)

Timmers HJ, Taieb D \& Pacak K 2012 Current and future anatomical and functional imaging approaches to pheochromocytoma and paraganglioma. Hormone and Metabolic Research 44 367-372. (doi:10.1055/ s-0031-1299712)

Tran Ba HP, Chao PZ, Benmansour F \& George B 2001 Long-term oncological results in 47 cases of jugular paraganglioma surgery with special emphasis on the facial nerve issue. Journal of Laryngology and Otology 115 981-987.

Ulrich S, Lehmann M, Ebmeyer J, Hamberger U, Reineke U, Dietrich U \& Sudhoff H 2009 Direct percutaneous embolization of a carotid body tumor with Onyx. HNO 57 1305-1310. (doi:10.1007/s00106-0091960-x)

Urquhart AC, Johnson JT, Myers EN \& Schechter GL 1994 Glomus vagale: paraganglioma of the vagus nerve. Laryngoscope 104 440-445. (doi:10.1288/00005537-199404000-00008)

Van Der Horst-Schrivers AN, Osinga TE, Kema IP, Van Der Laan BF \& Dullaart RP 2010 Dopamine excess in patients with head and neck paragangliomas. Anticancer Research 30 5153-5158.

Van Essen M, Krenning EP, Kooij PP, Bakker WH, Feelders RA, de Herder WW, Wolbers JG \& Kwekkeboom DJ 2006 Effects of therapy with [177Lu-DOTA0, Tyr3] octreotate in patients with paraganglioma, meningioma, small cell lung carcinoma, and melanoma. Journal of Nuclear Medicine 47 1599-1606.

Verniers DA, Keus RB, Schouwenburg PF \& Bartelink H 1992 Radiation therapy, an important mode of treatment for head and neck chemodectomas. European Journal of Cancer 28A 1028-1033. (doi:10.1016/0959-8049(92)90448-B)

Westerband A, Hunter GC, Cintora I, Coulthard SW, Hinni ML, Gentile AT, Devine J \& Mills JL 1998 Current trends in the detection and management of carotid body tumors. Journal of Vascular Surgery $\mathbf{2 8}$ 84-92. (doi:10.1016/S0741-5214(98)70203-4)

Young WF 2006 Paragangliomas: clinical overview. Annals of the New York Academy of Sciences 1073 21-29. (doi:10.1196/annals.1353.002)

Young WF \& Abboud AL 2006 Editorial: paraganglioma - all in the family. Journal of Clinical Endocrinology and Metabolism 91 790-792. (doi:10.1210/jc.2005-2758)

Zanelli M \& van der Walt JD 1996 Carotid body paraganglioma in von Hippel-Lindau disease: a rare association. Histopathology 29 178-181. (doi:10.1046/j.1365-2559.1996.d01-505.x)

Zanoletti E \& Mazzoni A 2006 Vagal paraganglioma. Skull Base 16 161-167. (doi:10.1055/s-2006-949519)

Zeitler DM, Glick J \& Har-El G 2010 Preoperative embolization in carotid body tumor surgery: is it required? Annals of Otology, Rhinology, and Laryngology 119 279-283.

Zovato S, Kumanova A, Dematte S, Sansovini M, Bodei L, Di Sarra D, Casagranda E, Severi S, Ambrosetti A, Schiavi F et al. 2012 Peptide receptor radionuclide therapy (PRRT) with 177Lu-DOTATATE in individuals with neck or mediastinal paraganglioma (PGL). Hormone and Metabolic Research 44 411-414. (doi:10.1055/s-0032-1311637)

Received in final form 30 July 2013

Accepted 6 August 2013

Made available online as an Accepted Preprint

6 August 2013 http://erc.endocrinology-journals.org DOI: $10.1530 / E R C-13-0223$
(C) 2013 Society for Endocrinology Printed in Great Britain
Published by Bioscientifica Ltd 